\title{
AGRITROPICA
}

Journal of Agricultural Sciences

Content is available at :

https://ejournal.unib.ac.id/index.php/jagritropica/index

ISSN 2621-217X (PRINT)

ISSN 2621-699X (ONLINE)

\section{Analysis of Factors Affecting General Suppliers to Sell FFB With A and B Quality to PT. Sandabi Indah Lestari and Risk Analysis of the Resources}

\author{
Ali Setia Iskandar1, Yuwana², and Bambang Sumantri ${ }^{3}$ \\ 1Postgraduate Program in Agribusiness, Faculty of Agriculture, University of Bengkulu \\ ${ }^{2}$ Dept. of Social Economics of Agriculture, Faculty of Agriculture, University of Bengkulu \\ ${ }^{3}$ Dept. of Agricultural Technology, Faculty of Agriculture, University of Bengkulu \\ Email addres : alilagi99@gmail.com
}

\begin{abstract}
This study studies to analyze the factors that influence general suppliers to choose FFB (Fresh Fruit Bunches) on quality and quality B and calculate the business expenses to be received. This research was conducted in the period August - September 2018 at PT. Sandabi Indah Lestari (SIL). The analytical tool used in this study is multiple linear regression analysis and risk analysis. Based on the results of the analysis, the factors that influence general suppliers choose to sell FFB at quality A and quality B at PT. SIL is the average factor of the weight of FFB supplied, the weight of FFB sorted, the distance to the plant and transportation costs, while the factors that do not significantly affect the long period of receiving FFB at the plant then for the risks received are known that the risk of selling FFB quality A is greater because of loss while FFB that sells quality B is smaller because it avoids losses.
\end{abstract}

Keyword: Suppliers, FFB (Fresh Fruit Bunches), quality A and B, risk

Citation to this paper should be made as follows :

Iskandar, A.S., Yuwana, and B. Sumantri. 2019. Analysis of Factors Affecting General Suppliers to Sell FFB With A and B Quality To PT. Sandabi Indah Lestari and Risk Analysis of the Resources. Agritropica: Journal of Agricultural Science. 2 (1): 1-12. DOI: https://doi.org/10.31186/J.Agritropica.2.1.1-12

\section{INTRODUCTION}

Oil palm is an important industrial plant producing oil, as well as fuel. In Bengkulu Province, the agricultural sector and plantation sub-sector have a share in the regional economy. The contribution of the agricultural sector in Bengkulu Province to smallholder plantations results in a total annual production of 809,681 Tons, with an area of 219,173 Ha (Direktorat Jendral Perkebunan, 2017).

PT. Sandabi Indah Lestari (SIL) is one of the private companies engaged in oil palm plantations. The company is located in Lubuk Banyau Village, Padang Jaya District, North Bengkulu Regency. At Palm Oil Mill at PT. SIL, the processing capacity of oil palm FFB reaches 45 Tons/Hour, so that to meet these needs, the mill processes FFB from 9
Tons/Hour (20\%) of core plantations and purchases from outside 36 Tons/hour $(80 \%)$ (PT. SIL, 2017). According to Rizki et al. (2014), the availability of raw materials in meeting production capacity is a very important factor in supporting the success of production. At PT. SIL to meet the shortage of raw materials, the company buys FFB raw materials from outside, namely plasma and general (farmers and collectors), the supply of raw materials from outside the company will be able to guarantee the availability of raw materials to meet the processing capacity of the plant.

In receiving FFB raw materials from general suppliers, PT. SIL has a policy on TBS quality standards, this standard is divided into quality A and quality B, as shown in the following Table. 
Table 1. Standard quality of FFB raw materials at PT. SIL

\begin{tabular}{lcc}
\hline \multicolumn{1}{c}{ Criteria } & B & A \\
\hline Bunch Weight & $0-8$ & $>8$ \\
Varitas & Dura/Tenera & Dura/Tenera \\
Raw & Back & Back \\
Convert & $75 \%$ & Back \\
Mature & Brondol 1 & Brondol 1 \\
Through Ripe & $45 \%$ & Back \\
Rotten & Back & Back i \\
Blank Bins & Back & Back \\
Price & $\mathrm{X}$ & $\mathrm{X}+100$ \\
\hline
\end{tabular}

Source: PT. SIL, 2017.

From the standard table of criteria for TBS raw materials that have been established there are differences in criteria between quality A and quality B. In each criterion, the weight of bunches for quality A must be more than $8 \mathrm{~kg} /$ bunch and for quality B there is no limit of $\mathrm{kg} /$ bunch, the criteria for varieties for quality A and B are the same, namely Dura / Tenera. In the raw criteria, bunches for quality $\mathrm{A}$ and $\mathrm{B}$ are returned, the calibration criteria for quality A are returned and B 75\% is returned. The mature criteria for quality $\mathrm{A}$ and $\mathrm{B}$ are the same, they must be brondol 1 , the criteria for quality A are returned and B 45 $\%$ returned, the bunch rot criteria for quality $A$ and $B$ are the same, which is returned. In the empty length criteria for quality $A$ and $B$ the same is returned, and the criteria for FFB prices for quality A are higher than Rp. 100 of price quality B.

Determining the value of proportions received by general suppliers from companies results that general suppliers are more likely to sell FFB at quality B than A, whereas companies want general suppliers to prefer quality A. This difference in choice is thought to be caused by other factors that affect the average factor of FFB supplied, the length of time the FFB is received at the factory, the weight of FFB that is sorted, the distance to the factory (mobility), and transportation costs, meaning that the general supplier selling FFB at quality $A$ and quality $B$ is always influenced by the factors mentioned above.

In determining the choice between selling on quality A and quality B by general suppliers, it will have an impact on the differences in business risk received by suppliers. This risk is often interpreted as uncertainty (uncertainty), so it can cause problems but can also bring opportunities that benefit the organization and individuals (Murtisari, 2013). Given the existence of these risks, so that general suppliers need to make the right decisions in selling with the selection of quality FFB that has been determined.

Based on the description above the objectives of this study are (1) to analyze the factors that influence general suppliers to choose FFB at quality A and quality B; (2) to calculate business risks received by general suppliers who sell FFB with quality $A$ and quality B.

\section{RESEARCH METHODS}

The research location is at PT. Sandabi Indah Lestari, Lubuk Banyau, Padang Jaya District, North Bengkulu Regency. The study was conducted in August - September 2018. The data and sources needed in this study are obtained in two ways, namely field research (field research) and library research (library research). Sampling in this study was conducted purposively (intentionally), namely to identify factors that influence general suppliers to choose FFB at quality $\mathrm{A}$ and quality $B$ and calculate business risks received by general suppliers selling FFB with quality A and quality B. Data collection is done by conducting interviews using questionnaires to 54 general suppliers who sell FFB to PT. SIL. 


\section{Data analysis method}

\section{Analysis of influencing factors}

The analytical tool used in this study is multiple linear regression analysis. This analysis is used to analyze the factors suspected of influencing general suppliers to choose quality $\mathrm{A}$ and quality $\mathrm{B}$ in selling their FFB. According to Ghozali (2005), mathematically the factors that influence the sale of FFB in quality A and B can be formulated in the equation as follows :

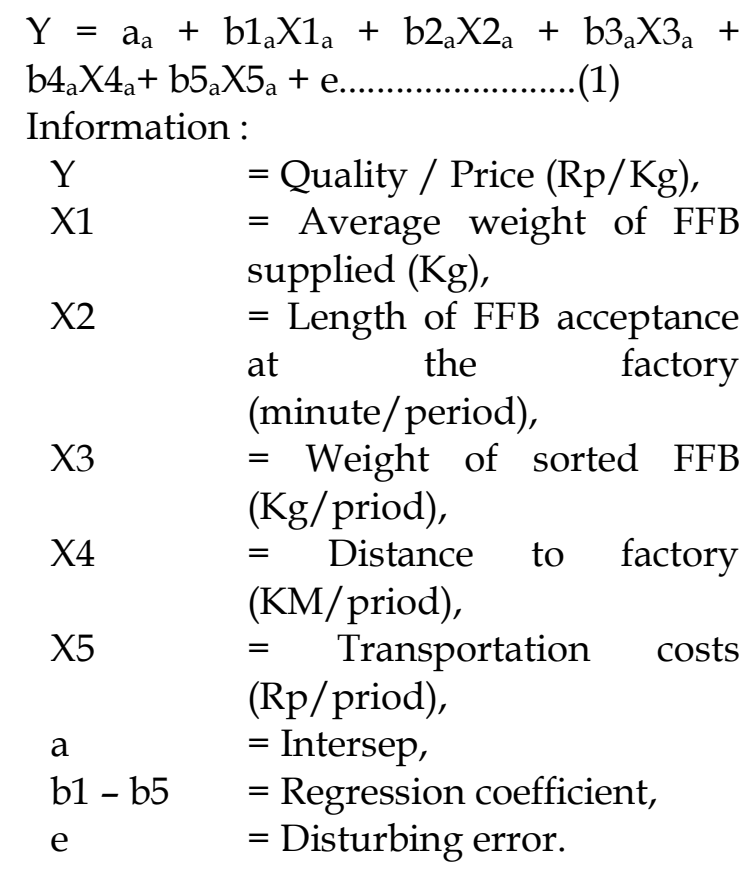

To find out whether the independent variables together influence the variables bound by the $\mathrm{F}$ test, while to determine the effect of each independent variable on the dependent variable, the T test is carried out, with a confidence level of $95 \%(\alpha=0.05)$.

\section{Risk Analysis}

Revenue is revenue minus costs incurred during the production process in one period, which is influenced by the amount of production produced and the price level that applies when the product is sold. Mathematically, according to Nur et al. (2015) and Soekartawi, et al (1993), the magnitude of risk can be calculated using the following formula: a. Income

Systematically income can be formulated as follows :

$$
\begin{aligned}
& \mathrm{Ei}=\mathrm{TR}-\mathrm{TC} \\
& \text { Information : } \\
& \mathrm{Ei}=\text { Income }(\mathrm{Rp}) \\
& \mathrm{TR}=\text { Total acceptance }(\mathrm{Rp}) \\
& \mathrm{TC}=\text { Total cost }(\mathrm{Rp})
\end{aligned}
$$

b. Expected Results (E)

The size for the expected results is the result of the mean (mean) of income can be formulated as follows :

$$
\begin{aligned}
& E=\sum_{\frac{i=1}{n}}^{n} E i \ldots \ldots \ldots \ldots \ldots \ldots \ldots(3) \\
& \text { Information : } \\
& \mathrm{E}=\text { Average income }(\mathrm{Rp}) \\
& \mathrm{Ei}=\text { Income }(\mathrm{Rp}) \\
& \mathrm{n}=\text { Number of FFB supply periods. }
\end{aligned}
$$

\section{c. Standard deviation (V)}

To calculate the standard deviation (standard deviation) consists of two stages used, the first calculates the size of the variance by the formula :

$$
\mathrm{V}^{2}=\frac{\sum_{i=1}^{n}(E i-E)^{2}}{\mathrm{n}-1} \ldots \ldots \ldots \ldots \ldots \ldots \ldots \ldots \ldots \ldots \ldots
$$

Standard deviation is the root of the variety with the formula:

$$
\begin{aligned}
& \mathrm{V}=\sqrt{\mathrm{V}^{2}} \ldots \ldots \ldots \ldots . . . . . . .(5) \\
& \text { Information : } \\
& \mathrm{V}^{2}=\text { Variety (variation) } \\
& \mathrm{V}=\text { Standard deviation of income }(\mathrm{Rp}) \\
& \mathrm{E}=\text { Average income }(\mathrm{Rp}) \\
& \mathrm{Ei}=\text { Income }(\mathrm{Rp}) \\
& \mathrm{n}=\text { Number of FFB supply periods. }
\end{aligned}
$$

\section{d. Coefficient of variation (CV)}

The general supplier risk level is determined based on the variation coefficient value, with the following formula :

$$
\mathrm{CV}=\frac{\mathrm{V}}{\mathrm{E}}
$$

Information :

$$
\mathrm{CV}=\text { Coefficient of variation }
$$


$\mathrm{V}=$ Standard deviation $(\mathrm{Rp})$

$\mathrm{E}=$ Average income $(\mathrm{Rp})$

\section{e. Lower limit (L)}

To calculate the lower limit, you can use mathematical equations as follows:

$\mathrm{L}=\mathrm{E}-2 \mathrm{~V}$

Information :

$\mathrm{L}=$ Lower income limit (Rp)

$\mathrm{E}=$ Expected average income (Rp)

$\mathrm{V}=$ Standard deviation.

According to Wiranti (2016), that the value of coefficient of variation $(\mathrm{CV})$ and lower limit (L) is safe or not, if the $\mathrm{CV}$ value is $<0.5$ and $\mathrm{L}$ value $>0$, then the business will avoid losses, otherwise if $\mathrm{CV}>0,5$ and the value of $\mathrm{L}<0$, the business can suffer losses, and will break even if the $\mathrm{CV}$ value $=0.5$ and the value of $\mathrm{L}=0$.

\section{RESULTS AND DISCUSSION}

Identification of General Supplier of Fresh Fruit Bunches (FFB) at PT. SIL
General suppliers are farmers and collectors who carry out activities to supply or sell FFB to the PT. SIL. Farmers who directly sell FFB to the factory without going through a collector are called direct distribution, while farmers who sell FFB through marketing institutions, namely traders, are called indirect distributions.

\section{Palm Oil FFB Sales at PT. Sandabi Indah Lestari}

\section{Affecting Factor Analysis}

Production of oil palm FFB quality A and quality $B$ is the result of purchasing FFB from general suppliers who choose to sell to PT. Sandabi Indah Lestari is based on the standard criteria for receiving FFB in quality $\mathrm{A}$ and quality $\mathrm{B}$. To determine the factors that influence the general supplier of selling FFB at quality A and quality B at PT.SIL, the data analysis is carried out. The analytical tool used in this study is multiple linear regression analysis using the Shazam program.

Table 2. Results of multiple linear regression analysis

\begin{tabular}{|c|c|c|c|}
\hline Variable & $\begin{array}{l}\text { Coefficient } \\
\text { Regression }\end{array}$ & $\begin{array}{l}\text { Standard } \\
\text { Error }\end{array}$ & T Count \\
\hline Constant & 305.35 & 165.6 & 1.514 \\
\hline Average weight of FFB supplied & 88.650 & 23.15 & $3.526^{* *}$ \\
\hline Duration of receiving FFB & 1.5202 & 1.199 & 1.268 \\
\hline Weight of FFB Disortized & -2.1865 & 3.544 & $-2.020^{* *}$ \\
\hline Mileage & 3.6537 & 0.961 & $3.802^{* *}$ \\
\hline Transportation costs & 1.0123 & 0.185 & $5.463^{* *}$ \\
\hline \multicolumn{4}{|l|}{$\mathrm{R}^{2}=0.7320$} \\
\hline \multicolumn{4}{|l|}{ F Count $=30.584$} \\
\hline \multicolumn{4}{|l|}{ T Table $(0,025 ; 48)= \pm 2,011$} \\
\hline \multicolumn{4}{|l|}{ F Table $(0,05)(5 ; 49)=2,45$} \\
\hline \multicolumn{4}{|l|}{ Source: Data from multiple regression analysis. } \\
\hline Information: ${ }^{* *}$ significant at $95 \%$ confidence level & . & & \\
\hline
\end{tabular}


In order for this model equation to be used for further analysis, the following tests are carried out :

\section{Coefficient of Determination $R 2$}

Known that the R2 value is 0.732 , meaning that the variables jointly influence the general supplier to sell FFB at quality A and quality $B$ with a value of $73.2 \%$. While the remaining $26.8 \%$ can be explained by other factors not examined in this study.

\section{F Test}

In this study, the $\mathrm{F}$ test is used to determine whether the variables in the model together have a significant effect or not on general suppliers selling FFB at quality $\mathrm{A}$ and quality B at PT. SIL by comparing the value of $\mathrm{F}$ count with $\mathrm{F}$ table. Table $\mathrm{F}$ value with $95 \%$ confidence level is 2.45. Known that the calculated $F$ value is 30,584 so it can be concluded that the value of $\mathrm{F}$ count $>\mathrm{F}$ table or $30.584>2.45$ then the decision taken is that $\mathrm{H}_{0}$ is rejected and $\mathrm{H}_{1}$ is accepted, meaning that the variables together significantly influence the general supplier of selling FFB at quality A and quality $B$ at PT. SIL.

\section{T test}

In this study the $\mathrm{T}$ test was used to determine whether each factor partially had a significant effect or not on general suppliers selling FFB at quality A and B by comparing the Thitung value with the $T$ value of the table as follows :

\section{a. Average weight of supplied FFB (X1)}

The results of the analysis show that on the average variable the weight of FFB supplied has a calculated $\mathrm{T}$ value of $3.526>\mathrm{T}$ table 2.011, then $\mathrm{H}_{0}$ is rejected and $\mathrm{H}_{1}$ is accepted which means that the average weight of FFB supplied has a significant influence on the general supplier of selling FFB at quality A and Quality B at PT. SIL. The calculation results indicate a positive correlation so that it can be indicated that the more heavily FFB supplied, the more general suppliers tend to choose to sell FFB at quality A at a higher price.
Based on research in the field this is influenced by the standard criteria set by PT. SIL as in Table 1, that is, between the two qualities that are determined to have different standard weight of bunches in their receipts, the difference in weight affects the yield of oil produced. On quality criteria A has a standard price level received and the minimum weight that can be received must be more than $8 \mathrm{~kg} /$ bunch, while quality $\mathrm{B}$ has a standard weight below $8 \mathrm{~kg} / \mathrm{bunch}$ is acceptable. This difference is the consideration of the general suppliers who sell FFB with an average weight of FFB of more than 8 $\mathrm{kg} /$ bunch to sell it at quality A.

The results of this study are in line with the results of previous research by Rizki et al. (2014), which also states that the weight or volume of FFB supplied has a significant effect on the selling price of FFB, because based on the results of research at PT. Bio Nusantara Teknologi, which applies quality classification standards, that the price difference for each class is Rp. $25.00 / \mathrm{kg}$, even though the difference is very small but it gives a considerable influence because the suppliers in a day sell FFB to PT. Bio Nusantara Technology is at least $3-4$ tons.

\section{b. Duration of receiving FFB (X2)}

The results of the analysis show that the variable length of FFB acceptance has a value of $\mathrm{T}$ count $1.268<\mathrm{T}$ table 2.011 , then $\mathrm{H}_{0}$ is accepted and $\mathrm{H}_{1}$ is rejected, meaning that the length of FFB acceptance does not have a significant effect on general suppliers selling FFB at quality A and quality B at PT . SIL. This gives an indication that the length of time or not acceptance is not used as a general indicator in general suppliers selling FFB at quality A and quality B to PT. SIL.

Based on observations in the field that the results of this analysis are influenced by the results of time measurements starting from general suppliers who queue up vehicles to FFB until they are received in loading ramp for processing, it is known that in FFB sales general suppliers do not pay attention or take into account the time or not needed in the admission process. This makes the FFB receipt 
time does not affect the general suppliers in selling FFB at quality A and quality B to PT. SIL.

The results of this study are inversely proportional to the research of Andreas, et al. (2017), which states that the length of the waiting time affects the selling price of FFB in the factory, because the longer the waiting time can result in a decrease in the quality of fruit received by the factory. The quality of FFB includes the percentage of tenera and dura fruit, the level of fruit maturity (percentage of brondol) and fruit fruit, but the most influential is the percentage of fruit rest due to the length of handling FFB (Rizki et al., 2014).

\section{c. Averageortized FFB (X3)}

The results of the analysis show that on the average variable FFB that is sorted has a calculated $\mathrm{T}$ value $-2,020<\mathrm{T}$ table $-2,011$, then $\mathrm{H}_{0}$ is rejected and $\mathrm{H}_{1}$ is accepted meaning that the average FFB disortified has a significant effect on general suppliers selling FFB at quality A and quality B at PT. SIL.

The calculation results show a negative correlation so that it can be indicated that the fewer FFBs that are sorted out the more influential the general supplier in choosing to sell FFB at quality A at a higher price. This condition occurs because with the least sortage received and a high price, the general suppliers can get maximum income.

Based on observations in the field of general suppliers, usually in the sale of FFB more adjust to sell at the desired quality based on the condition of the FFB they carry. This is because in selling FFB suppliers must pay attention to the differences in acceptance standards for each quality A and quality B, because if it is not considered, it can cause a large number of received sortages, so that it can have an impact on general suppliers.

The results of this study are in line with Erpendi's study, (2012) which states that the weight of FFB that sorts significantly influences the selling price of FFB in the factory. In addition, based on research by Rizki et al. (2014) states that calculating the average weight of fruit can determine the price of FFB received, which is divided into 3 (three) classes namely class A average weight of fruit $>12 \mathrm{~kg} /$ bunch, class $B$ average weight of fruit between $7-12 \mathrm{~kg}$ / bunch while class C has an average weight of fruit between 5-7 $\mathrm{kg} /$ bunch, so that with the standard weight set then suppliers who cannot fulfill it can be subject to sorting on the FFB they sell.

\section{d. Mileage to factory (X4)}

The results of the analysis show that the distance traveled to the factory has a value of $\mathrm{T}$ count $3.802>\mathrm{T}$ table 2.011, then $\mathrm{H}_{0}$ is rejected and $\mathrm{H}_{1}$ is accepted meaning that the distance to the factory has a significant influence on the general supplier selling FFB at quality A and quality B at PT. SIL.

The calculation results indicate a positive correlation so that it can be indicated that the farther the distance to the factory, the general supplier tends to choose to sell FFB at quality $\mathrm{A}$ at a higher price. This is due to the long distance, besides the high cost required, distance can also affect the condition of FFB to be sold. According to Budiyanto et al (2005), oil palm FFB after harvesting until it reaches the loading ramp should not be more than 12 hours. Based on this, the risk of FFB conditions which can decrease in quality is due to distance, so suppliers want to sell at high prices, besides that, PT. SIL also made a policy that mileage had an effect on the provision of price subsidies, namely the further the distance traveled, the price received would be higher than the supply of FFB which had a closer distance. With the acceptance of high prices, it is expected that suppliers obtain appropriate income, but from the results of the study it is known that there are still general suppliers selling FFB at quality $B$, this occurs because general suppliers also consider the condition of FFB to be sold with the quality criteria applied. by PT. SIL.

The results of this study are in line with the results of Erpendi study, (2012), which states that the distance has a significant relationship with the sale of FFB by suppliers, this occurs because the distance is getting farther then the price received will be higher so as to provide greater income compared to suppliers that are closer. 


\section{e. Transportation costs (X5)}

The results of the analysis show that the transportation cost variable has a calculated $\mathrm{T}$ value of $5.463>\mathrm{T}$ table 2.011, then $\mathrm{H}_{0}$ is rejected and $\mathrm{H}_{1}$ is accepted, meaning that transportation costs have a significant influence on general suppliers selling FFB at quality A and quality B at PT. SIL. The calculation results indicate a positive correlation so that it can be indicated that the higher the cost required, the general supplier is more likely to choose to sell FFB at quality A at a higher price.

The need for high costs in supplying FFB makes general suppliers more willing to sell at higher prices in order to obtain revenue that is commensurate with the costs they bear. Based on the results of the study, it is known that there are still general suppliers selling FFB at quality B, this is because the general supplier also adjusts between the conditions of FFB sold with the quality criteria standards applied by PT. SIL.

The results of this study are in line with the results of Andreas, et al. (2017) which also states that transportation costs have a significant effect on the selling price of FFB, this is because general suppliers will choose to sell FFB to the factory at a high price in accordance with the cost of transporting it to the factory so as not to harm them.

\section{Operating costs}

Operational costs are expenditures related to operations, namely all expenditures directly used for the production or purchase of traded goods include general costs, sales, administration, and loan interest (Mulyadi, 2002).
Operational costs are costs that must be spent so that the activities or operations of a business continue. Operational costs include fixed costs and variable costs.

Based on the data, it is produced that in each quality, there is a difference in the amount of costs required, namely for quality A with a total cost of Rp. 4,196,253/Month and for supply costs in quality $\mathrm{B}$ of $\mathrm{Rp}$. $7,092,160 /$ Month, where each quality has the equation that the need for variable costs is higher than the fixed costs, this is due to uncertain prices and usage.

From the processed data, it can be seen that the biggest expenditure is in the supply process for quality $B$. The difference in the amount of operational costs is due to the production of supply of quality B FFB which is higher than the supply of quality $A$, thus affecting the costs required.

\section{Variable Costs}

Variable costs or also called variable costs are costs for which the total amount changes proportional to the change in volume of activity or production but the number per unit does not change (Kartika, 2009).

From the results of processed Table 4, it can be seen that in one month the process of supplying FFB to PT. SIL the amount of variable costs needed for labor wages, fuel oil and oil at the supply of quality A FFB of Rp. 4,027,916/Month, and for supplying FFB to quality B, a fee of Rp. 6,877,067/Month. From this result, the variable cost for supplying FFB at quality $B$ is higher than the supply of FFB in quality $\mathrm{A}$, this is due to the high difference in FFB production supplied, resulting in an increase in vehicle operational intensity, which increases the required costs.

Table 3. Operating costs for general suppliers of quality A and quality B FFB

\begin{tabular}{llccrr}
\hline \multirow{2}{*}{ No } & Description & \multicolumn{2}{c}{ Total Cost (Rp/Month) } & \multicolumn{2}{c}{ Percentage (\%) } \\
\cline { 3 - 6 } & & $\mathrm{A}$ & $\mathrm{B}$ & $\mathrm{A}$ & $\mathrm{B}$ \\
\hline 1. & Variable Costs & 4.027 .917 & 6.877 .067 & 96 & 97 \\
2. & Fixed cost & 168.336 & 215.093 & 4 & 3 \\
\hline & Total & 4.196 .253 & 7.092 .160 & 100 & 100 \\
\hline
\end{tabular}

Source: Processed results of primary data in 2018 
Table 4. Variable costs of supplying quality A and B FFB by general suppliers

\begin{tabular}{|c|c|c|c|c|c|}
\hline \multirow[t]{2}{*}{ No } & \multirow[t]{2}{*}{ Description } & \multicolumn{2}{|c|}{ Average cost (Rp/Month) } & \multicolumn{2}{|c|}{ Percentage (\%) } \\
\hline & & $\mathrm{A}$ & $\mathrm{B}$ & $\mathrm{A}$ & $\mathrm{B}$ \\
\hline 1 & Labor & 2.462 .500 & 4.390 .000 & 61 & 63 \\
\hline 2 & Fuel Oil (BBM & 1.458 .333 & 2.306 .667 & 36 & 34 \\
\hline 3 & Oil & 107.083 & 180.400 & 3 & 3 \\
\hline & Total & 4.027 .916 & 6.877 .067 & 100 & 100 \\
\hline
\end{tabular}

Source: Processed results of primary data in 2018

\section{Labor}

This workforce comes from family labor and outside family labor, where for the costs needed in the use of labor for quality A an average of Rp. $2,462,500 /$ Month, while for the average cost required for quality $\mathrm{B}$, the average is Rp. 6,877,067/Month. From the results of the research conducted, it is known that the use of quality A workforce on average tends to use family labor for its business activities, this is due to the production or sale of FFB that is not too much, so that when using outside labor to facilitate business wages can reduce income or even suffer losses because it is not in accordance with the production produced. While the use of labor for general suppliers of quality $B$ on the average uses labor from outside with some of them who are still assisted by family labor, this is done because of the high production or sale of FFB, so that sufficient energy is needed to facilitate their business.

\section{Fuel Oil (BBM)}

Fuel oil (BBM) is a fuel containing energy needed by a vehicle in its operational motion. The high cost of fuel used is due to the high mobility of vehicles used in the process of supplying FFB to PT. SIL. In the process of supplying FFB between quality $\mathrm{A}$ and quality $\mathrm{B}$ has a different amount of production of FFB supply, so this affects the high cost of fuel needed, where for quality $\mathrm{A}$ requires an average cost of Rp. 1,458,333/Month, while for fuel costs on quality $B$ requires a higher average cost of Rp. 2,306,667/Month.

\section{Oil}

Engine oil becomes a very important part to support the work of the engine along with the use of the engine, there is a decrease in the quality and function, so it must be replaced in a private manner. In supplying FFB, general suppliers distribute FFB to PT. SIL with different intensities, so this affects the quantity of oil change, where to supply FFB to quality A requires an average oil change cost of Rp. $107,083 /$ Month, while for the primers the change of oil at the supply of FFB in quality $B$ requires an average cost of $R p$. 180,400 /Month, so it is known that the cost of oil change for the supply of quality $B$ TBS is higher than quality A, this occurs because of the mobility of higher supply activities, which results in a high distance of vehicle usage, resulting in short oil life.

\section{Fixed cost}

Fixed costs are types of costs that are static (unchanging) in a certain size. We will still spend this fee even if we do not do very much activity. In the process of producing fixed costs we will always pay or spend without calculating how much production we do, whether when not producing or vice versa when production is carried out in maximum capacity.

From Table 5, it can be seen that in one month the process of supplying FFB to PT. SIL the amount of fixed costs needed for depreciation of equipment and vehicle tax on the supply of quality A FFB of Rp. 5.206.744/Month, and for supply of FFB on quality B, a fee of Rp. 215,093/Month. Based on these results, the fixed costs for supplying FFB at quality $B$ are higher than the supply of FFB at quality A. 
Table 5. Fixed costs of supplying quality A and B FFB by general suppliers

\begin{tabular}{|c|c|c|c|c|c|}
\hline \multirow[t]{2}{*}{ No } & \multirow[t]{2}{*}{ Description } & \multicolumn{2}{|c|}{ Average cost (Rp/Month) } & \multicolumn{2}{|c|}{ Percentage (\%) } \\
\hline & & $\mathrm{A}$ & $\mathrm{B}$ & $\mathrm{A}$ & $\mathrm{B}$ \\
\hline 1. & Tool Depreciation & 101.667 & 101.667 & 42 & 43 \\
\hline 2. & Vehicle tax & 66.669 & 113.426 & 58 & 57 \\
\hline & Total & 168.336 & 215.093 & 100 & 100 \\
\hline
\end{tabular}

Source: Processed results of primary data in 2018

The difference in the amount of this cost is due to the difference in the high cost of vehicle tax, where vehicle tax costs for quality A suppliers are lower than B quality, this is because the average vehicle that supplies quality $A$ is a small vehicle (Pick Up), while for suppliers $B$ the average vehicle used is a large vehicle (Truck), so this affects the high vehicle tax costs that must be borne by general suppliers.

Depreciation of tools is the value contained in a tool by looking at the initial price, final price, usage time, and number of items. In this study the depreciation cost of tools for supplying FFB at quality $\mathrm{A}$ and quality B is the same which is Rp. 101,667. Equipment used by general suppliers for their businesses includes :

a. Tojok

Tojok is a tool from an iron pipe made with a T-shaped grip design with a pointed tip. This tool serves to move FFB by plugging in the palm oil jang that you want to move.

\section{b. Scales}

Scales are tools used to measure the weight of FFB. With these scales, we can determine the weight of FFB sold by farmers, so that with the amount of weight obtained, it can determine the money that will be obtained by farmers by multiplying between the weight at the set price. c. Slope

Kerenjang is a circularly designed tool usually made of woven rattan and nets from mines with a capacity of $\pm 100 \mathrm{~kg}$. This tool is useful in the weighing process, where the work system of this tool is with the shells linked to the scales, so that the thickness can accommodate the FFB that the farmers want to weigh.

\section{d. Gancu}

Gancu is a tool from an iron pipe like a corner but is made with an ordinary grip design like a machete with a pointed curved tip. This tool serves to move FFB by linking it to the palm oil table that you want to move. This tool is very important because it is very useful in the weighing, FFB sorting process, and helps in tidying the TBS trip arrangement in the truck.

\section{Costs, Receipts, and Revenues}

Income is the amount of money received by the company from the sale of products (goods or services) from customers and not from investment. According to Soekartawi (1995), income is divided into two, namely gross income and net income. Gross income (revenue) is the total production value of farms in a certain period of time, whether sold, and consumed by the household itself, or stored, and net income is the difference between gross income and production costs.

Table 6. Total costs, revenues and revenues from businesses

\begin{tabular}{rlrr}
\hline No & \multicolumn{1}{c}{ Description } & \multicolumn{3}{c}{ Total (Rp/Month) } \\
\cline { 3 - 4 } & & \multicolumn{1}{c}{$\mathrm{A}$} \\
\hline 1. & Cost & 4.192 .920 & 7.092 .160 \\
2. & Reception & 104.835 .535 & 209.388 .728 \\
3. & Income & 100.642 .615 & 202.296 .569 \\
\hline
\end{tabular}

Source: Processed results of primary data in 2018 
Based on Table 6 , it can be seen that the costs needed are based on the sum of variable costs and fixed costs, so the costs for general suppliers that sell FFB at quality A are Rp. 4,192,920/Month, and the quality B is Rp. $7,092,160$ /Month. The revenue is obtained from the multiplication of the amount of production with the selling price, so for general suppliers who sell FFB on quality A, the amount of revenue is $\mathrm{Rp}$. $104,835,535 /$ Month and at quality B suppliers of Rp. 209,388,728/Month, based on the results of the reduction between revenues and costs, it can be seen the amount of income for those who supply FFB at quality $A$ is Rp. $100,642,615$ /Month and for quality B suppliers of Rp. 202,296,569 /Month.

Study the amount of business revenue of general suppliers is influenced by the number of FFB sales and the total cost of business, where the higher the level of FFB sales supported by high purchase prices, the higher the income. Based on the results of this study, it can be seen that revenues are greater than costs and income, this is because the costs needed in the business are not fixed.

\section{Business Risk Analysis}

In determining the choice between selling on quality A and quality B by general suppliers. Based on the handling standards and prices that have been set differently, it will have an impact on the differences in business risks received by suppliers. This risk is often interpreted as uncertainty (uncertainty), so it can cause problems but can also bring opportunities that benefit the organization and individuals (Murtisari, 2013). In this business, general suppliers must always consider the risks borne by income. The risks borne by general suppliers who sell FFB to PT.SIL are income risk. Business risk analysis can be seen in Table 7 below.
Based on the results of the risk analysis, it can be seen that the average income (E) for suppliers selling FFB at quality A is Rp. 100,642,615, while those that supply B quality are Rp. 202,296,569. Then for standard deviation $(\mathrm{V})$, it is known that for suppliers selling FFB at quality A, Rp. 55,988,424, and those who supply quality B are Rp. 54,672,188.

The amount of risk can be known by looking at the relationship $\mathrm{E}$ and $\mathrm{V}$ through the measurement of the coefficient of variation $(\mathrm{CV})$ and the lower limit of income (L). According to Wiranti (2016), that the coefficient of variation $(\mathrm{CV})$ and lower limit (L) is safe or not, if the CV value is $<0.5$ and the $\mathrm{L}$ value is $>0$, then the risk is low, conversely if $\mathrm{CV}>0.5$ and $\mathrm{L}$ value $<0$ is high risk, and will break even if $\mathrm{CV}$ value $=0.5$ and $\mathrm{L}$ value $=0$. Then from the results of data analysis in the Table obtained for the variation coefficient value (CV) for suppliers of quality A amounted to 0.55631 , with a nominal value of the lower limit (L) of Rp. - 11,334,233, because the $C V$ value is $>0.5$ and the $L$ value is $>0$, then the business has a high risk, then the variation coefficient value $(\mathrm{CV})$ for suppliers of quality $B$ is 0.27026 , with a nominal value of the lower limit (L) Rp. $27,970,581$, with this result, $\mathrm{CV}<0.5$ and $\mathrm{L}$ value $>0$, so the business has a low risk.

Based on the results of the analysis, it is known that between suppliers who sell FFB on quality $\mathrm{A}$ and $\mathrm{B}$ have different business risks, because if compared between the magnitude of the risk that will be received by suppliers of quality A and B FFB, then the risk of selling FFB to quality $A$ is more higher than those selling FFB at quality B. This is because the income received by a general supplier who sells FFB at quality B is sufficient to cover the costs incurred in his business.

Table 7. Business risk analysis

\begin{tabular}{rlll}
\hline No & \multicolumn{1}{c}{ Description } & \multicolumn{1}{c}{ Value } \\
\cline { 3 - 4 } & & \multicolumn{1}{c}{$\mathrm{A}$} & \multicolumn{1}{c}{$\mathrm{B}$} \\
\hline 1. & Mean $(E)$ & Rp. 100.642.615 & Rp. 202.296.569 \\
2. & Standard Deviation $(\mathrm{V})$ & Rp. 55.988.424 & Rp. 54.672.188 \\
3. & Coefficient of Variation $(C V)$ & 0,55631 & 0,27026 \\
4. & Lower Income Limit (L) & Rp. - 11.334.233 & Rp. 27.970.581 \\
\hline
\end{tabular}

Source: Calculation results from primary data in 2018. 
Based on observations in the field, the results of the calculation of the risk obtained occur because between suppliers or sellers of FFB in quality $\mathrm{A}$ and quality $\mathrm{B}$ have different price determinations where the price of FFB quality $A$ is higher than the price of quality $B$. In addition to paying attention to price differences, suppliers also pay attention to the standard FFB sales revenue at quality A which is higher than the standard FFB acceptance on quality $B$, so suppliers pay more attention to FFB acceptance standards than the difference in price levels to be received, due to the majority of FFB quality those sold by suppliers have a tendency towards quality $\mathrm{B}$, so that if FFB is sold at quality A then FFB will be much sorted and have an impact on the amount of losses received by general suppliers. This is what affects the difference in risk that will be accepted by suppliers of quality A and quality B.

\section{CONCLUSIONS}

1. Factors affecting general suppliers choose to sell FFB at quality A and quality B, namely the average weight of FFB supplied, the weight of FFB sorted, the distance to the factory and transportation costs. The long time factor for receiving FFB at the factory does not significantly affect general suppliers in selling FFB at quality A and quality B at PT. SIL.

2. The results of the calculation of business risk received by general suppliers selling FFB at quality A and quality B can be known from each income average. Based on this, it can be seen that the variation coefficient value $(\mathrm{CV})$ for suppliers of quality $\mathrm{A}$ is 0.55631 , with the nominal value of the lower limit (L) of Rp. $11,334,233$, then $C V>0.5$ and $L$ value $>0$, so that the risk is high. The results of the variation coefficient value $(\mathrm{CV})$ for quality B suppliers are 0.27026 , with the lower limit nominal value (L) of $\mathrm{Rp}$. 27,970,581, then $C V<0.5$ and $L$ value $>0$, so it has a low risk.
It is suggested that in determining the standard criteria for receiving FFB between quality A and quality B, the company should pay attention to the factors that influence general suppliers in selling their FFB. In achieving maximum revenue, suppliers should pay more attention to the quality of FFB to be sold, so that in the sale of suppliers, they can get high prices with little sorting.

\section{REFERENCES}

Andreas, W. K., L. Sutiarso, K. W. Harto. 2017. Optimization of the Quality of Palm Oil Fresh Fruit Bunches in the Harvest-Harvest Process Using Dynamic Models. Agritech, Department of Agricultural Industry Technology, Faculty of Agricultural Technology, Gadjah Mada University, Jl. Flora No. 1, Bulaksumur, Yogyakarta 55281, Indonesia. 37 (1): 101-107

Budiyanto, P. Imam, and A. Fidayat. 2005. Analysis of the Relationship between FFB Quality and Quality of CPO at PT. Agromuko Bunga Tanjung. National Seminar on Science and Technology, University of Lampung. 14 (1): 433 - 446.

Directorate General of Plantation. 2017. Plantation Statistics Indonesia Tree Crap Estate Statistics of Indonesia, Palm Oil Palm Oil; Jakarta. 81 p.

Erpendi, 2012. Analysis of Factors Affecting Sales of FFB (Fresh Fruit Bunches) at Anugerah KUD in Bagan Sinembah Sub-District, Rokan Hilir Regency. Department of Management, Faculty of Economics and Social Sciences, Islamic University of Sultan Syarif Kasim Riau, Pekanbaru. 1 (1): 1-83.

Ghozali, I. 2005. Application of Multivariate Analysis with SPSS Program. Diponegoro University, Semarang. 3 (5): 146 - 158.

Kartika, I. 2009. Tofu Agroindustry Financial Analysis after the Issue of Formalin Tofu in Banyumas Regency. 
Agricultural Sciences, Department of Socio-Economic Agriculture,

UNSOED Purwokerto. 24 (2): 35 - 60.

Mulyadi. 2002. Agricultural Economics. Social

Economic Education and Information Research Institute. Jakarta. $180 \mathrm{p}$.

Murtisari, A. 2013. Estimates of Income and Risks in Cocoa Farming in Mananggu District, Boalemo District. Gorontalo State University Journal Jl.Jend.Sudirman No.6 Gorontalo City. 1 (1): 1-6.

Nur, H., A., Fembriarti E., P., Wuryaningsih D., S., 2015. Analysis of Income and Risk of Cabbage Farming in Dry Land and Rainfed Rice Fields in Gisting District, Tanggamus District. Journal of Agribusiness Department, Faculty of Agriculture, University of Lampung, Jl. Prof. Dr. Soemantri Brojonegoro No.1 Bandar Lampung. 3 (1): 1-9.
PT. SIL. 2017. Profile of PT. Sandabi Indah Lestari. Banyau Sub-Village, North Bengkulu. 63 p.

Rizki, J., Nusril, and Asriani P., S. 2014. Analysis of Handling the Acceptance of Fresh Fruit Bunches at PT. Bio Nusantara Teknologi in Pondok Kelapa District, Bengkulu Tengah Regency. Agricultural SocioEconomic Faculty of Agriculture, University of Bengkulu. 14 (1): 104131.

Soekartawi, Rusmiadi, and Damaijati E. 1993. Risks and Uncertainty in Agribusiness (Theory and Application). Raja Grafindo Persada. Jakarta. 85 p.

Soekartawi. 1995. Analysis of Farming. UIPress, Jakarta. $80 \mathrm{p}$.

Wiranti, A. 2016. Analisis Risiko Usaha Jamur Tiram di Kota Bengkulu. Program Studi Agribisnis Jurusan Ekonomi Pertanian Fakultas Pertanian Universtitas Bengkulu . 5 (1) : 1 -15 